\title{
Molecular phylogeny of Mesometridae (Trematoda, Digenea) WITH ITS RELATION TO MORPHOLOGICAL CHANGES IN PARASITES
}

\author{
JOUSSON O.***, BARTOLI P.** \& PAWLOWSKI J.****
}

\begin{abstract}
Summary :
Complete ITS (Internal Transcribed Spacer) ribosomal DNA sequences were obtained for the six species know at present time within the Mesometridae Poche, 1926. The adull stages are intestinal parasites of herbivorous sparid teleosts. Aligned sequences were analysed with Maximum Parsimony, Maximum Likelihood and Neighbor-joining phylogenetic methods to infer evolutionary relationships among mesometrid species. The ITSbased phylogeny obtained showed the two Wardula species as a sister group to other Mesometridae, and as compared to morphological data, suggest some general tendencies in the morphological evolution of this group. It consists mainly in changes from elongated to subcircular forms, regression of the pharynx, and the development of a strong accessory attachment organ.
\end{abstract}

KEY WORDS : phylogeny, Mesometridae, Digenea, rDNA, Internal Transcribed Spacer, specialization.
Résumé : Phylogénie des Mesometridae (Trematoda, Digenea) ET ÉVOLUTION MORPHOLOGIQUE ENTRE ESPĖCES PARASITES

Les séquences complètes de la région ITS /internal Transcribed Spacer) de l'ADN ribosomique ont été obtenues pour les six espèces actuellement connues de la famille des Mesometridae Poche, 1926. Les stades adultes sont des parasites intestinaux des sparidés herbivores. Les séquences alignées des six espèces ont été analysées avec les méthodes de reconstruction phylogénétique Maximum Parsimony, Maximum Likelihood et Neighborjoining, en vue d'établir leurs liens de parenté. La phylogénie ainsi abtenve a montré que les deux espèces du genre Wardula constifuent un groupe frère par rapport aux autres espèces de cette famille. La comparaison des analyses de séquences et des structures anatomiques de chaque espèce suggère une tendance évolutive caractérisée par le passage d'une morphologie allongée à une forme subcirculaire, une régression du pharynx ainsi que le développement d'un puissant organe accessoire servant à l'attachement.

MOTS CLÉS : phylogénie, Mesometridae, Digenea, ADN ribosomique, Internal Transcribed Spocer, spécialisation.

three species of the Mesometridae (Wardula capitellata, Elstia stossichianum and Centroderma spinosissima), using ITS rDNA sequences analysis (Jousson et al., 1998). The Mesometridae are mainly characterized by the absence of a ventral sucker, the development of an accessory attachment organ, and a reticular excretory system. The taxonomy of this family has been notably revised by Paggi \& Orecchia (1964). These authors divided the Mesometridae into Mesometrinae and Wardulinae subfamilies on the basis of vitellaria distribution and testes position. Recent descriptions of the mesometrid adults (Bartoli, 1987; Bartoli \& Gibson, 1989) showed the presence of a strong pharynx in Wardula species only. This character, added to those retained by Paggi \& Orecchia (1964), supports the division of mesometrids into Wardulinae and Mesometrinae.

Recently, several PCR-based methods of genotype analysis have been developed for the purposes of taxonomic identification of parasites (Mac Manus \& Bowles, 1996). Internal Transcribed Spacer (ITS) of the nuclear ribosomal DNA (rDNA) region sequencing has been used for species distinction and phylogenetic analyses within many digenean genera, e.g. Dolichosaccus

\footnotetext{
Département de Zoologie et Biologie Animale, Université de Genève, CH-1224 Chêne-Bougeries, Suisse.

- Centre d'Océanologie de Marseille, U.M.R. CNRS 6540 Dimar, F13288 Marseille, France.

Muséum d'Histoire Naturelle, CH-1211 Genève 6, Suisse.

Correspondence: Olivier Jousson, Département de Zoologie et Biologie Animale, Université de Genève, Station de Zoologie, 154, route de Malagnou, CH-1224 Chênes-Bougeries, Suisse. Tel:: 004122/3498644 - Fax: 004122/3492647 -

E-mail: jousson2@sc2a.unige.ch
} 
(Luton et al., 1992), Fasciola (Adlard et al., 1993), Echinostoma (Morgan \& Blair, 1995) and Schistosoma (Desprès et al., 1995). These studies showed that the ITS rDNA is characterized by a high nucleotide substitution rate, particularly in ITS1, demonstrating its ability to distinguish between closely related species. Another reason for choosing the ITS region is its accessibility. It is flanked by conserved sequences which can be used in the design of primers for amplification by the polymerase chain reaction (PCR). Furthermore, the presence of multiple copies in each cell provides large number of target sequences for PCR.

In this study, the complete ITS rDNA sequences from the six species constituting the Mesometridae were used to elucidate phylogenetic relationships among this group.

\section{MATERIAL AND METHODS}

DNA ISOLATION, PCR AMPLIFICATION, CLONING AND SEQUENCING

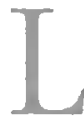

iving adult specimens of the six mesometrid species: Mesometra orbicularis (196 specimens), $\perp$ M. bracbycoelia (78), Centroderma spinosissima (72), Elstia stossichianum (176), Wardula capitellata (6) and $W$. sarguicola (4) were isolated from the digestive tract of their definitive hosts, 37 individuals of Sarpa salpa for the five first species and 10 individuals of Diplodus sargus (Sparidae) for the last one. The fishes were collected from the north-western Mediterranean coast (Marseille, France).

DNA from the six species of Mesometridae was extracted in guanidin lysis buffer, precipitated with isopropanol and disolved in distilled water. PCR amplifications were performed in a total volume of $50 \mu \mathrm{l}$ with an amplification profile consisting of 40 cycles of $30 \mathrm{~s}$ at $93.5^{\circ} \mathrm{C}, 30 \mathrm{~s}$ at $50^{\circ} \mathrm{C}$ and $120 \mathrm{~s}$ at $72{ }^{\circ} \mathrm{C}$, followed by five min at $72{ }^{\circ} \mathrm{C}$ for final extension. The ITS $1+$ $5,8 \mathrm{~S}+$ ITS2 region of the rDNA was amplified using universal primers localized in conserved regions of the $18 \mathrm{~S}$ rDNA (5'-TAACAGGTCTGTGAT-3') and 285 rDNA (5'-TTCACTCGCCATTACT-3'). Amplified PCR products were purified using High Pure PCR Purification Kit (Boehringer), and were either ligated in the $\mathrm{p}-\mathrm{GEM}-\mathrm{T}$ Vector (Promega) and cloned in the XL-2 Ultracompetent Cells (Stratagene) or sequenced directly with the fmol DNA Sequencing System (Promega) using $\alpha-S^{35}$ isotope, all according to the instructions of the manufacturers.

\section{SEQUENCE ANALYSIS}

As an outgroup taxa, we choosed the I'TS rDNA sequences of the closely related digenean species to
Mesometridae available in the EMBL/GenBank database, which are the two echinostomatids Echinostoma trivolvis and $E$. revolutum. Complete ITS sequences were aligned manually using the GDE 2.2 (Larsen et al., 1993) and analysed using the following methods: the neighbor-joining ( $\mathrm{NJ}$ ) method (Saitou \& Nei, 1987) applied to distances corrected for multiple hits, and for unequal transition and transversion rates using Kimura's two-parameter model (Kimura, 1980), the maximum parsimony (MP) method, using heuristic search with the branch swapping option included in PAUP 3.1.1 (Swofford, 1993) and the maximum likelihood (ML) method with a transitions/transversions ratio of 2 , as implemented in the fast DNAm1 program (Olsen et al.,1994). The reliability of internal branches in the $\mathrm{NJ}$, MP and ML trees was assessed using the bootstrap method (Felsenstein, 1988), with 500 replicates for NJ and 100 replicates for MP and ML trees. The PHYLOWIN program (Galtier \& Gouy, 1996) was used for distance computations, NJ and ML trees building and bootstraping.

\section{RESULTS}

P CR amplification of the ITS rDNA and part of the $18 S$ and 285 rDNA region from the Mesometridae give a single product for which size varies from 1550 to $1800 \mathrm{bp}$, depending on the species. The PCR products averaged 1550 bp in Mesometra orbicularis, $M$. brachycoelia, Wardula capitellata and W. sarguicola, 1670 bp in Centroderma spinosissima, and $1800 \mathrm{bp}$ in Elstia stossichianum, respectively.

The subsequent sequencing of amplified fragment shows that these differences are due mainly to the presence of a 85 bp long domain near 5 ' end of the ITS1, which is repeated twice in C. spinosissima, and four times in E. stossichianum. The complete sequences of PCR products, including ITS1 + 5.8S + ITS2 were obtained for all specimens. The length of the ITS region reaches up to 1119 bp in Mesometra orbicularis, 1129 bp in $M$. brachycoelia, 1218 bp in Centroderma spinosissima, 1352 bp in Elstia stossichianum, 1078 bp in Wardula capitellata, $1125 \mathrm{bp}$ in $W$. sarguicola, 1046 bp in Echinostoma revolutum, and 1047 bp in $E$. trivolvis, respectively. The interspecific variability within the Mesometridae ranges from $6.6 \%$ to $19.1 \%$ in ITS 1 , which is slightly higher than in ITS2 (3.4-15.1\%).

The phylogenetic analysis of Mesometridae inferred from ITS rDNA sequences using NJ, MP and ML methods gives identical results (Fig. 1). The trees were rooted with ITS sequences of both echinostomatids Echinostoma trivolvis and E. revolutum (see Morgan \& Blair, 1995). All analyses show the group composed of the two species of the genus Wardula as a sister 
0.045 substitution/site
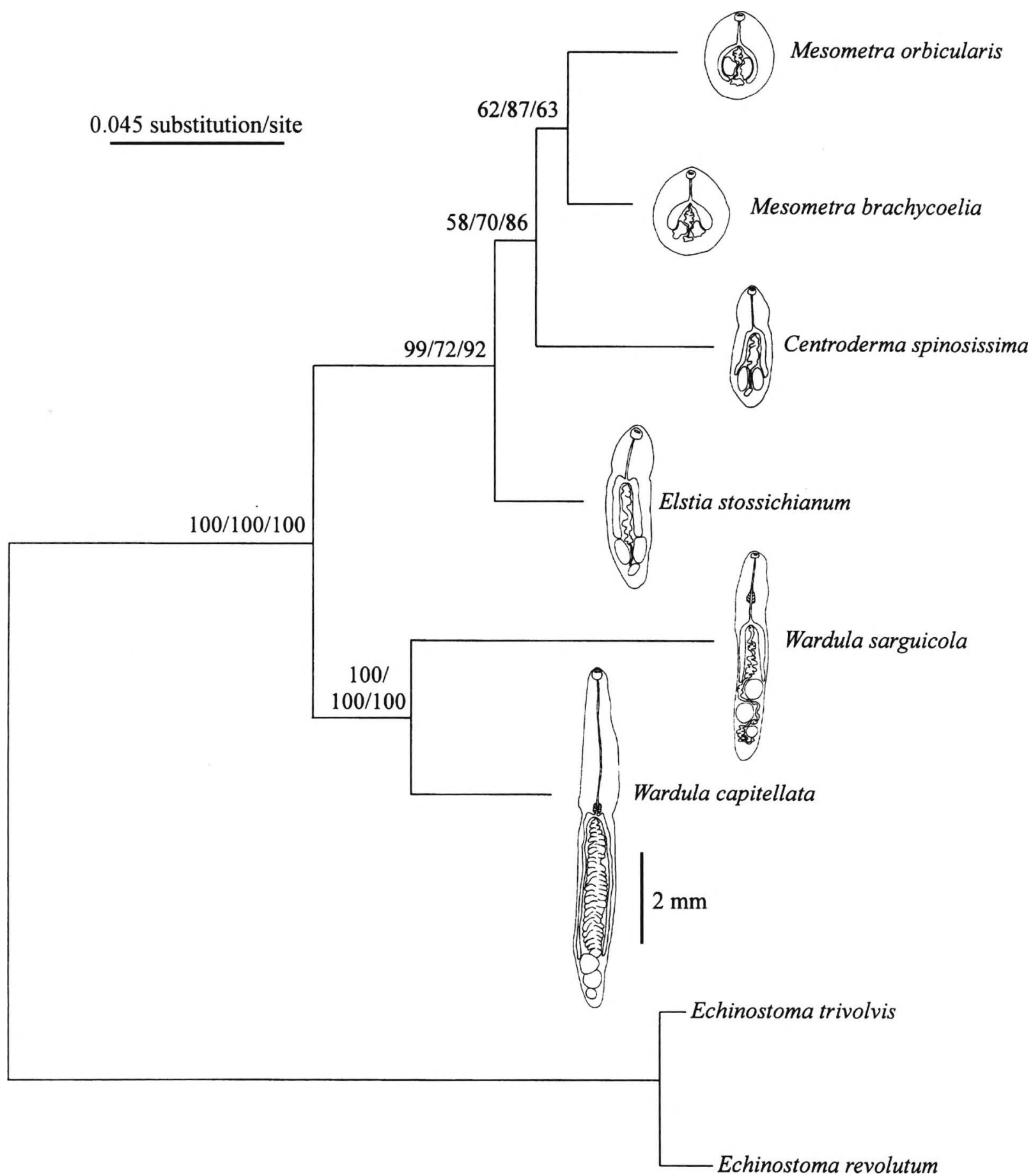

Fig. 1. - Phylogeny of Mesometridae inferred from ITS rDNA sequences using the Neighbor-Joining method (pairwise gap removal option) including schematic morphology of adult specimens. Bootstrap values are given for NJ/MP/ML trees along branches. ML tree: $\ln (\mathrm{L})=$ $-2764,437$. MP tree: length $=566$; consistency index $=0,922$; retention index $=0,871$. 
group to other Mesometridae. The relationships between other four species are not well resolved. Two Mesometra species branch together, but seem to be as closely related to each other as they are to Centroderma spinosissima. Elstia stossichianum appears as a sister group to these three species.

\section{DISCUSSION}

Whe current report was designed to establish the phylogenetic relationships among the Mesometridae, which are intestinal parasites of herbivorous sparid teleosts. Relative to Echinostomatidae, the ITS rDNA-based sequences analyses of all species of Mesometridae showed with $100 \%$ bootstrap support that both Wardula species constitute a sister group to other Mesometridae, thus supporting their division into subfamilies Mesometrinae and Wardulinae based on morphological and anatomical criteria, according to Paggi \& Orecchia (1964). However, such tree topology should be confirmed by analyses using a closely related outgroup taxa, as representatives of Microscaphidiidae Looss, 1900 or Notocotylidae Lühe, 1909 (see Brooks et al., 1985). The ITS1 region is the most variable in the examined rDNA fragment and possesses a short domain that can be repeated in some species, making possible their discrimination based on size comparison of the PCR products. A similar repeated domain was previously described in the ITS1 from another digenean fluke, Dolichosaccus sp. (Luton et al., 1992).

Interestingly, the phylogenetic analyses have resulted in an evolutionary hypothesis for the mesometrid species that correlates well with the morphological characteristics used by authors to distinguish species (Paggi \& Orecchia, 1964; Bartoli, 1987). A progressive reduction of the body size from supposed ancestral Wardula to derived Mesometra is observed. This reduction is accompagned by changes from elongated to subcircular body shape. Moreover, the ventral side of the body becomes entirely concave in subcircular Mesometra, while only the anterior part is concave in the other species. This character can be interpreted as an adaptation conferring better attachment to the intestinal epithelium of its definitive host Sarpa salpa (Bartoli, 1987). The same interpretation was given by Choi et al. (1995) to the concavity of the body observed in an other digenean, Gymnophalloides seoi. Evolutionary changes from Wardulinae to Mesometrinae also include a tendency toward a reduction in the number of eggs, a regression of the pharynx and an increase in the circularity of the digestive caeca, which tend to surround genital glands. However, the morphological specialization observed among Mesometridae cannot be associated with an increase of host specificity from ancestral Wardula to derived Mesometra. Probably, it should exists a relationship between the specialization of the trematoda found in $S$. salpa, and the abundance of this host, according to Basset (1992) who suggested that specialized parasites occur preferentially in predictible hosts. In fact, all mesometrids are oioxenous parasites, i.e. they infect a single host species (Sey, 1968 and 1970; Papoutsoglou, 1976; Orecchia \& Paggi, 1978; Fischthal, 1980; Bray, 1984; Bartoli, 1987; Bartoli \& Gibson, 1989), possibly due to the mode of definitive's host infection of the Mesometridae. Indeed, there are very few herbivorous fish species in the Mediterranean (Verlaque, 1990); this could explain the oioxeny of the Mesometridae, in contrast with the quite low definitive-host specificity noticed among the Digenea (Lymbery, 1989).

Our results confirmed the suitability of the ITS rDNA for studying phylogenetic relationships between closely related species of digenetic flukes and suggested a high specialization level of subcircular Mesometra species to the smooth intestinal epithelium of their herbivorous definitive host.

\section{REFERENCES}

Adlaki) R.D., Barker S.C., Blair D. \& Cribb T.H. Comparison of the second internal transcribed spacer (ribosomal DNA) from populations and species of Fasciolidae (Digenea). International Journal for Parasitology, 1993, 23, 423-425.

BArToli P. Caractères adaptatifs des Digènes intestinaux de Sarpa salpa (Teleostei, Sparidae) et leur interprétation en termes d'évolution. Annales de Parasitologie Humaine et Comparée, 1987., 62, 542-576.

BARTOLI P. \& Gibson D.I. Wardula sarguicola n. sp. (Digenea, Mesometridae), a rectal parasite of Diplodus sargus (Teleostei, Sparidae) in the western mediterranean. Annales de Parasitologie Humaine et Comparée, 1989, 64 (1), 20-29.

BASSET Y. Host specificity of arboreal and free-living insect herbivores in rain forests. Biological Joumal of the Linnean Society, 1992, 47, 115-133.

BRAY R.A. Some helminths parasites of marine fishes and cephalopods of south Africa: Aspidogastrea, Haplosplanchnidae, Mesometridae and Fellodistomatidae. Journal of Natural History, 1984, 18, 271-292.

Brooks D.R., O'Grady R.T. \& Glen D.R. Phylogenetic analysis of the Digenea (Platyhelminthes, Cercomeria) with comments on their adaptative radiation. Canadian Journal of Zoology, 1985, $63:$ 411-443.

Chol M.H., PARK W.J., ChaI J.Y. \& LeE S.H. Surface ultrastructure of metacercaria and adult of Gymnophalloides seoi (Digenea: Gymnophallidae). Korean Journal of Parasitology, 1995, 33, 289-296.

Despres L., Kruger F.J., Imiert-Establet D. \& Adamson M.L. ITS2 ribosomal RNA indicates Schistosoma bippopotami is a distinct species. International Journal for Parasitology, 1995, 25, 1509-1514 
Felsenstein J. Phylogenies from molecular sequences: inference and reliability. Annual Review of Genetics, 1988, 22, 521-565.

FischTHAL J.H. Some digenetic trematodes of marine fishes from Israel's Mediterranean coast and their zoogeography, especially those from Red Sea fishes. Zoologica scripta, $1980,9,11-23$.

GALTIER N. \& GouY M. SEAVIEW and PHYLO-WIN: two graphic tools for sequence alignment and molecular phylogeny. Computer Applications in the Biosciences, 1996, 12, 543-548.

Jousson O., Bartoli P., Zaninetti L. \& Pawlowski J. Use of the ITS rDNA for elucidation of some life-cycles of Mesometridae (Trematoda, Digenea). International Joumal for Parasitologv, 1998, 28, 1403-1411.

KIMLRA M. A simple method for estimating evolutionnary rates of base substitutions through comparative studies of nucleotide sequences. Journal of Molecular Evolution, $1980,16,111-120$

Larsen N., Osen G.J., Maidak B.L., Mc Caughey M.J, Overbeek R., Macke T.J., Marsh T.L. \& Woese C.R. The ribosomal database project. Nucleic Acids Research, 1993, 21, 30213023.

Luton K., Walker D. \& Blair D. Comparisons of ribosomal internal transcribed spacer from two congeneric species of flukes (Platyhelminthes: Trematoda: Digenea). Molecular and Biocbemical Parasitology, 1992, 56, 323-328.

LYMBERY A.J. Host specificity, host range and host preference. Parasitology Today, 1989, 5, 298.

MaC Manus D.P. \& Bowles J. Molecular Genetic Approaches to Parasite Identification: their Value in Diagnostic Parasitology and Systematics. International Joumal for Parasitology, 1996, 26, 687-704.

MORGAN J.A.T. \& BLAIR D. Nuclear rDNA ITS sequence variation in the trematode genus Echinostoma: an aid to establishing relationships within the 37-collar-group. Parasitology, 1995, 111, 609-615.

Olsen G.J., Matsuida H., Hagstrom R. \& Overbeek R. Fast DNAm1: a tool for construction of phylogenetics trees of DNA sequences using maximum likelihood. Computer Applications in the Biosciences, 1994, 10, 41-48.

Orecchia P. \& PAGgi L. Aspetti di sistematica e di ecologica degli elminti parassiti di pesci marini studiati presso, l'istituto di parassitologia del' universita di Roma. Parassitologia, 1978, 20, 73-79.

PAGgi L. \& Orecchia P. I monostomi parassiti di Box salpa. Revisione della famiglia Mesometridae Poche, 1926. Parassitologia, 1964, 6, 283-311

PAPOUTSOGlou S.E. Metazoan parasites of fishes from Saronicos gulf. Athens-Greece. Thalassograpbica, 1976, 1, 69102.

SaITOU N. \& NeI M. The Neighbor-Joining method: a new method for reconstructing phylogenetic trees. Molecular Biology and Evolution,1987, 4, 406-425

SEY O. Parasitic helminths occuring in Adriatic fishes. Part I (Flukes). Acta Adriatica, 1968, 13 (4), 3-15.
SEY O. Parasitic helminths occuring in Adriatic fishes. Part II (Flukes and tapeworms). Acta Adriatica, 1970, 13 (6), 315 .

SwOFFORI D.L. PAUP: phylogenetic analysis using parsimony. version 3.1 Illinois Narural History Survey, Champaign, Illinois, 1993.

VERLAQUE M. Relations entre Sarpa salpa (Linnaeus, 1758) (Téléostéen, Sparidae), les autres poissons brouteurs et le phytobenthos algal méditerranéen. Oceanologica acta, 1990,13 (3), 373-388.

Reçu le 25 avril 1998 Accepté le 14 septembre 1998 